\title{
Global Comparative Study on REDD+ story of change Supporting district-level jurisdictional approaches in Indonesia
}

\author{
Sandy Nofyanza, Swetha Peteru, Tobias Thürer and Amy E Duchelle
}

\section{Key messages}

- Through a strong partnership with an association of district governments, Lingkar Temu Kabupaten Lestari (the Sustainable Districts Association, or LTKL), and earlier efforts to showcase the sustainability progress of subnational jurisdictions, CIFOR has continued its work on jurisdictional approaches to low-emission rural development in Indonesian districts.

- The CIFOR-LTKL partnership began in 2019 but has already yielded results, like contributions to a jurisdictional approach concept note that has now been integrated into Indonesia's national development planning document, as well as the creation of the first ever district-level jurisdictional profile (in Sintang District, West Kalimantan), launched at the 2020 Global Landscapes Forum.

- Together with LTKL, CIFOR co-designed the questionnaire and data collection techniques for Kerangka Daya Saing Daerah (Regional Competitiveness Framework, or KDSD), a monitoring and reporting system developed by LTKL Secretariat and its member districts to measure districts' progress towards the Sustainable Development Goals (SDGs). CIFOR also developed training and implementation guidelines for KDSD.

- The jurisdictional approach is scaling up, with more LTKL member districts showing interest in implementing the KDSD and in creating a jurisdictional profile.

\section{Introduction: Building on early research on jurisdictional approaches}

A jurisdictional approach to low-emission rural development is a comprehensive way to balance competing socioeconomic and environmental interests across an entire political territory. Such approaches have been gaining traction globally, with governments typically playing a central role thus enabling better alignment of sustainable development initiatives and activities with public policies (Boyd et al. 2018). Subnational jurisdictions like provinces and districts are recognized as key for implementing a jurisdictional approach, since they both possess some legal authority and are close to communities making land-use decisions (Stickler et al. 2018a). Taking actions at subnational level can also help to emphasize how important forests and local-level governance are when it comes to global climate change mitigation (de Sassi et al. 2014, Wunder et al. 2020). Today, jurisdictional approaches build on over a decade of Reducing Emissions from Deforestation and Forest Degradation (REDD+) implementation experience, as well as private-sector experience of acting upon sustainability commitments (Seymour et al. 2020); both having the aim of addressing multiple interconnected objectives across scales and sectors while promoting equitable stakeholder involvement.

Since 2010, through the Global Comparative Study on REDD+ (GCS REDD+), CIFOR has been assessing the performance of subnational and local REDD+ initiatives in six tropical forest countries (Sills et al. 2014) - including the world's first jurisdictional REDD+ programme in Acre, Brazil (Duchelle et al. 2014) - as well as examining governance challenges for REDD+ across multiple levels (Ravikumar et al. 2015). Expanding on this work, in 2016 and 2017 CIFOR formed a strategic alliance with Earth Innovation Institute (EII), the Governors' Climate and Forest Task Force (GCF-TF), and the Climate, Community 
and Biodiversity Alliance (CCBA), to focus more purposefully on subnational jurisdictional approaches in the context of REDD+. Together, these partners have now evaluated the state of jurisdictional sustainability across 35 GCF-TF member jurisdictions and four other jurisdictions in 12 tropical countries (Stickler et al. 2018b). As well as a synthesis report aimed at policymakers, this evaluation resulted in the publication of analytical briefs about each jurisdiction, known as 'jurisdictional profiles'.' The partners also assessed enabling conditions for sustainability in a subset of these jurisdictions, using the CCBA Sustainable Landscapes Rating Tool (Peteru et al. 2021).

This 'story of change', which was coordinated by CIFOR's Research to Impact evaluation team, describes ongoing CIFOR activities to support the districtlevel implementation of jurisdictional approaches in Indonesia. It highlights progress to date, mapped against the theory of change ${ }^{2}$, as well as potential directions for future research and engagement. The evidence presented here was collected by an independent consultant through interviews with 10 key stakeholders and a review of secondary data, including government reports and regulations. A sense-making workshop with key scientists was also conducted to analyse the evidence collected.

\section{Actionable knowledge and engagement on jurisdictional approaches}

In 2019, CIFOR began work with Lingkar Temu Kabupaten Lestari ${ }^{3}$ (LTKL), focusing on assessments of sustainability progress in Indonesian districts. CIFOR supported LTKL to finalize indicators for its Kerangka Daya Saing Daerah (Regional Competitiveness Framework, or KDSD), co-developing the associated questionnaire and data collection techniques. KDSD is a synthesis of various performance indicators, including those required for the Ministry of Home Affairs (Kemendagri) reporting. It was developed by the LTKL Secretariat and its member districts, as a means to measure and evaluate the progress of each district in terms of achieving national targets, including the

\footnotetext{
1 The jurisdictional profiles are available at https://www.cifor.org/ knowledge/publication/6999/

2 The narrative in this infobrief along the theory of change impact pathway. A graphical depiction is provided in Figure 1.

3 LTKL is a network of 9 active member districts from 6 Indonesian provinces working with partners to advance their sustainability agendas.
}

Sustainable Development Goals (LTKL n.d., Syahrani et al. 2020). As a starting point, LTKL and its member districts have agreed to first focus on agricultural commodity supply chain transformation, particularly for oil palm, coconut, cocoa, rubber, spices, coffee and non-timber forest products (LTKL 2019). As such, KDSD also combines indicators on sustainable production of these commodities as expected by potential market and investors for the producing jurisdictions. A more streamlined and credible voluntary monitoring and reporting system as envisioned under KDSD is expected to increase districts' competitiveness and attractiveness for new and sustainable investments. KDSD is currently being piloted in the districts of Gorontalo (Gorontalo), Siak (Riau) and Sintang (West Kalimantan). CIFOR also developed guidelines for KDSD training and its implementation, and is also supporting LTKL districts to showcase their sustainability progress and potential to attract new and 'green' investments, through creating district-level jurisdictional profiles.

\section{From concept note development to showcasing districts' sustainability progress}

A strong partnership and high level of trust between CIFOR and LTKL has strengthened the work on jurisdictional approaches. At a national level, this partnership opened the door for CIFOR to help develop a jurisdictional approach concept note, spearheaded by the National Development Planning Agency (Bappenas) and facilitated by the LTKL Secretariat. Bappenas used this concept note as a basis to integrate the jurisdictional approach into the 2020-2024 National Mid-Term Development Planning Document, or RPJMN (Seymour et al. 2020, Government of Indonesia 2020) - a clear indicator confirming the importance of jurisdictional approaches in contemporary Indonesian development discourse. CIFOR's experience in assessing and documenting the state of jurisdictional sustainability at provincial and state level also proved to be an asset in developing that concept note, as one LTKL Secretariat informant acknowledged: "We invited CIFOR [to the jurisdictional approach concept note development at Bappenas] as one of the key organizations that could provide insights to the working team... especially about what CIFOR has done at the provincial level."The respondent was referring to the "jurisdictional profiles' prepared by CIFOR and Ell that enable provincial and state-level jurisdictions to showcase their sustainability progress. 
At the district level, CIFOR has also been lending its expertise to LTKL to establish the methodology and other technical aspects of the processes behind KDSD processes. The LTKL Secretariat and CIFOR jointly organized workshops that were held in Bogor and three KDSD pilot districts in late 2019. The Bogor workshop aimed to bring together partners from districts and key ministries and organizations to introduce KDSD, as well as to reach an agreement on its foundation, discuss data collection and methods, and inform participants about CIFOR's jurisdictional approach research. The district workshops had similar goals, with the additional aim to further strengthen alignment with Laporan Penyelenggaraan Pemerintahan Daerah (Regional Government Administration Report, or LPPD) with representatives of Kemendagri, build stakeholders' capacity to implement KDSD, and help them form the district's KDSD implementation teams comprised of both state and non-state actors. ${ }^{4}$ Such activities are critical to the success of this approach; with district governments leading KDSD implementation as well as data collection, there needs to be a high sense of ownership around the initiative for it to succeed. Representatives of diverse stakeholder organizations conveyed in interviews that, through these workshops, CIFOR equipped the districts with the necessary capacities to apply the KDSD tool.

Through establishing an impact measurement and evaluation framework, CIFOR has continued to support the LTKL Secretariat in showcasing the regional economic and sustainability potential of its member districts, so as to attract new and 'green' investments. This collaboration has led to the co-creation of the first ever district-level jurisdictional profile for Sintang District (Sukri et al. 2020), along with district government representatives, non-governmental organizations (NGOs), community associations, and academics. Together with CIFOR and LTKL, the Government of Sintang District launched this profile at the 2020 Global Landscapes Forum (GLF). ${ }^{5}$ According to the LTKL Secretariat, the opportunity to showcase districts' sustainability progress achievements on such a global

\footnotetext{
4 The KDSD implementation teams in Sintang and Gorontalo have been formalized through the Bupati of Sintang with Letter of Assignment No. 049/4991/II-BAPPEDA/2019, and through the Bupati of Gorontalo, who issued Decree (SK) No. 255/28/III/2020. Although not yet formalized, a KDSD team has also been established in Siak and data collection is ongoing.

5 https://events.globallandscapesforum.org/agenda/biodiversity2020/29-october-2020/lessons-from-indonesia-building-a-naturebased-economy-through-jurisdictional-approaches/
}

platform is an incentive that can reinvigorate district governments, especially when it comes to their sustainability initiatives and monitoring.

The progress seen in the three KDSD pilot districts is linked to three interconnected, pre-existing factors at the local level (see Box 1): (i) a strong commitment to sustainability among district governments and their leaders; (ii) the presence of non-state actors actively participating in the district development discourse; and (iii) the presence of multistakeholder forums for sustainable development.

The progress seen to date is also attributable to the direct technical support provided by CIFOR researchers through the change process. One notable example of this is from a CIFOR researcher, who has provided direct responses and ongoing technical support to the LTKL Secretariat over the course of two years. This researcher and LTKL have been directly involved in helping with the district's needs, including through trainings provided via district-level workshops and in an advisory role whenever the data collection process hits an obstacle. At present, the researcher continues to assist the LTKL Secretariat as the districts conduct primary data collection, for instance by providing technical guidelines for focus group discussions.

\section{Box 1. A district-level overview of enabling conditions for sustainability and KDSD}

Being LTKL members, all the three pilot jurisdictions and their leaders (Bupati) have recognized the importance of developing sustainable agricultural supply chains. Through establishing Siak Hijau (Green Siak) and Sintang Lestari (Sustainable Sintang), the districts of Siak and Sintang have committed to comprehensive sustainable natural resource management (Sedagho Siak and Government of Siak District 2019, Government of Sintang District 2019), while Gorontalo has committed 10 per cent of its budget to climate change adaptation initiatives (Transformasi 2017). Besides government agencies there are various influential actors in the mix, including universities, the Private Sector Coalition for Green Siak (KPPSH - Siak), civil society organizations (e.g., Kito Siak in Siak, Japesda in Gorontalo and FKMS in Sintang), and development partners (e.g., CSF and WWF in Sintang and Sedagho Siak in Siak). Sintang Government in particular has established a multistakeholder forum called the Joint Secretariat to coordinate the implementation of Sintang Lestari. Together these factors have contributed to the achievements seen so far during KDSD processes. 


\section{A work-in-progress and opportunities for future research and engagement}

The workshops co-organized by LTKL Secretariat and CIFOR have successfully helped in: (i) kickstarting KDSD data collection in all pilot districts; (ii) creating the structure of the KDSD working team; and (iii) setting a timeline and goals. The workshops also highlighted the importance of bringing all relevant stakeholders to the table, as described by a senior lecturer and researcher from Gorontalo State University (UNG): "After the first meeting CIFOR was involved in, we realized that if we wanted to formulate a [jurisdictional] profile and implement KDSD, it would not be possible if only this many people were involved. At the second meeting we expanded and invited more people. So, in addition to government officials and university representatives, we also invited farmers' groups and civil society organizations (CSOs)."

As of August 2020, Sintang District had compiled about 72 percent of the data needed for KDSD, ahead of Gorontalo and Siak (TFA 2020). The start date and pace of progress in the data collection process in each district varies due to differences in institutional capacities, issues pertaining to data (e.g., availability, format), different degrees of pre-existing support from non-state actors (like development organizations or (SOs), and multistakeholder forums, among other reasons. Overall progression has been significantly slower than expected due to the COVID-19 pandemic, as mobility restrictions were put in place and district governments had to reallocate their budgets to focus on pandemic-related measures. Despite this, the districts remain committed to KDSD implementation during this challenging time, as stated by a high-level Siak District official who pledged to "restart and reconvene all the parties involved, including government agencies, the private sector and other relevant organizations." Additionally, the jurisdictional profiles, which were welcomed as a way to "promote a jurisdiction in a short, concise and cost-effective manner", are also still in the pipeline. LTKL and CIFOR are aiming to publish a couple more of profiles by mid-2021, helping the districts to showcase themselves on a global platform.

The data and information collected in the districts will feed into a 'Regional Competitiveness Report'. This report will portray the conditions, existing enabling environment, and potential for sustainable investments in the districts as well as multistakeholder collaboration to support the progress (LTKL n.d.). The report will be jointly prepared by each district's KDSD team, supported by LTKL Secretariat. CIFOR is currently assisting LTKL to develop the template of this report, holding monthly multistakeholder workshops for template consultations from the end of April until mid-2021.

A local-level monitoring and reporting tool like the KDSD could help address multiple issues at both national and subnational levels, like those surrounding land rights and local-level planning and investments. The majority of district-level respondents are optimistic that the data and information collected for KDSD could help district governments to "decide which strategic agricultural programmes [should] be included in planning, which are competitive at scale, and which could drive the local economy further", as well as help clarify and align the efforts and interests of various district government agencies (e.g., Organisasi Perangkat Daerah, OPD) working on similar issues, including permit issuance and investments. Clear data and spatial information on smallholders' concessions will also help in obtaining sustainability certifications, potentially leading to livelihood and environmental benefits. The ongoing data collection may also spill over to inform the implementation of other nationwide initiatives, like the agrarian reform (Tanah Objek Reforma Agraria, TORA) and social forestry scheme.

All of these potential achievements could be fully realized if KDSD is integrated into the national government reporting system (LTKL n.d.), for example in the mandatory LPPD to Kemendagri and Sustainable Development Goal reporting to National SDGs

Secretariat and other relevant ministries. Integration into the national reporting system would mean certainty and the sustainability of the framework as a subnational MRV system. Thus far, KDSD shows potential, as it is "easier to view and measure, potentially making progress evaluation faster", as conveyed by a high-level Siak District official. The decision to first focus on sustainable agricultural supply chain transformation as an entry point is also strategic, as this subject intersects with many other issues of interest to districts (e.g., social forestry and forest fires); this opens up the possibility for this initiative to evolve into a comprehensive, cross-sectoral 'green' economic reform approach.

Permanence, however, requires real change to first be materialized (e.g., proven to deliver real socioeconomic benefits and environmental protection) and documented, and this requires constant commitment, lasting efforts, and continuous advocacy from all key stakeholders at all levels. To this end, the three 
pilot districts (which underwent regional elections in December 2020) have reaffirmed their commitments to continue implementation of KDSD and sustainable supply chain transformation. Most importantly, the districts are in the process of preparing new regional development planning documents (Rencana Pembangunan Jangka Menengah Daerah, RPJMD) and have committed to strategize jurisdictional approaches in their development plans, following the example of the National Mid-Term Development Planning Document (RPJMN). However, the timelines for RPJMD development vary, as the Bupati-elect were inaugurated at different times (e.g., 26 February 2021 for Gorontalo and 17 June 2021 for Siak).

More Indonesian districts have started to develop an interest in sustainability initiatives and innovative policies, in accordance with the national sustainable development agenda. Siak, for example, recently become one of the first districts to establish an ecological fiscal transfer scheme from districts to village governments (known as TAPE) ${ }^{6}$, while Sintang has been conducting corporate social responsibility awards in an effort to engage and reward companies taking part in sustainability initiatives. Some of the preliminary outcomes from the LTKL-CIFOR partnership in particular have encouraged other LTKL districts to pilot framework implementation and create a jurisdictional profile of their own (e.g., Musi Banyuasin and Aceh Tamiang). However, balancing economic and livelihood imperatives with environmental and climate agenda remains a work in progress.

The policies, initiatives and actions implemented at all levels to date have led to various achievements, but the work is far from over. By the end of 2020, there were six provinces and one district with ongoing jurisdictional REDD+ programmes in Indonesia.? This number grows if we expand the scope beyond REDD+ and include ongoing subnational initiatives like KDSD or the jurisdictional sustainable palm oil initiatives that were mandated under the National Action Plan for Sustainable Palm Oil (Rencana Aksi Nasional Perkebunan Kelapa Sawit Berkelanjutan, RAN-KSB). ${ }^{8}$ Thus, considering

6 TAPE is being developed in other LTKL member districts, like Sanggau (West Kalimantan) and Sigi (Central Sulawesi).

7 https://www.reddprojectsdatabase.org/view/projects.php?id=360\& name $=$ Indonesia\&type $=$ program

8 Institut Pertanian Bogor (IPB University) and Bappenas, with support of LTKL and GIZ Indonesia, are preparing a Guideline to Regional Plantation Planning based on a jurisdictional approach (applicable for oil palm). According to a GIZ Indonesia representative: "one thing that really stands out in this guideline, and this is adapted from KDSD, is the emphasis on multistakeholder development." the various measures taken so far, CIFOR has identified the need to provide more systematic evidence to understand which policies and actions work best, under what circumstances, and in which combinations ("what works where, for whom and why?") to deliver 3E (effective, efficient and equitable) outcomes to promote transformational change in the forestry and land-use sectors.

\section{Conclusion}

Jurisdictional approaches to REDD+ and to lowemission development are beginning to take hold. As a research institution with extensive knowledge and experience on jurisdictional approaches, CIFOR found itself in a strategic position in Indonesia: able to contribute to the jurisdictional approach concept note developed for Indonesia's national development planning document (RPJMN), and now influencing jurisdictional approach implementation at district level. However, the work CIFOR and its strategic partners have done to support jurisdictional sustainability at district level has only just begun. The progress to date is attributable to various pre-existing factors at the local level, like strong and ongoing districtlevel commitments to sustainability and persistent support from non-state actors in district development discourse, as well as the presence of a CIFOR researcher embedded in the change process. In the near term, CIFOR's GCS REDD+ research programme will continue to share knowledge and lend expertise to LTKL and other strategic partners in pursuit of jurisdictional sustainability in Indonesian districts, including helping more LTKL members through the sustainable commodity initiative and KDSD implementation.

\section{Acknowledgments}

This research is part of CIFOR's Global Comparative Study on REDD+ (http://www.cifor.org/gcs). Funding support for this study was provided by the Norwegian Agency for Development Cooperation (Norad); the International Climate Initiative (IKI) of the German Federal Ministry for the Environment, Nature Conservation and Nuclear Safety (BMU) and the CGIAR Fund as part of the CGIAR Research Program on Forests, Trees and Agroforestry (FTA), led by CIFOR. The opinions expressed here are those of the authors, and do not necessarily reflect the views of CIFOR, CGIAR or the donors. The authors also thank the LTKL Secretariat for its support in the development of this 'story of change'. 

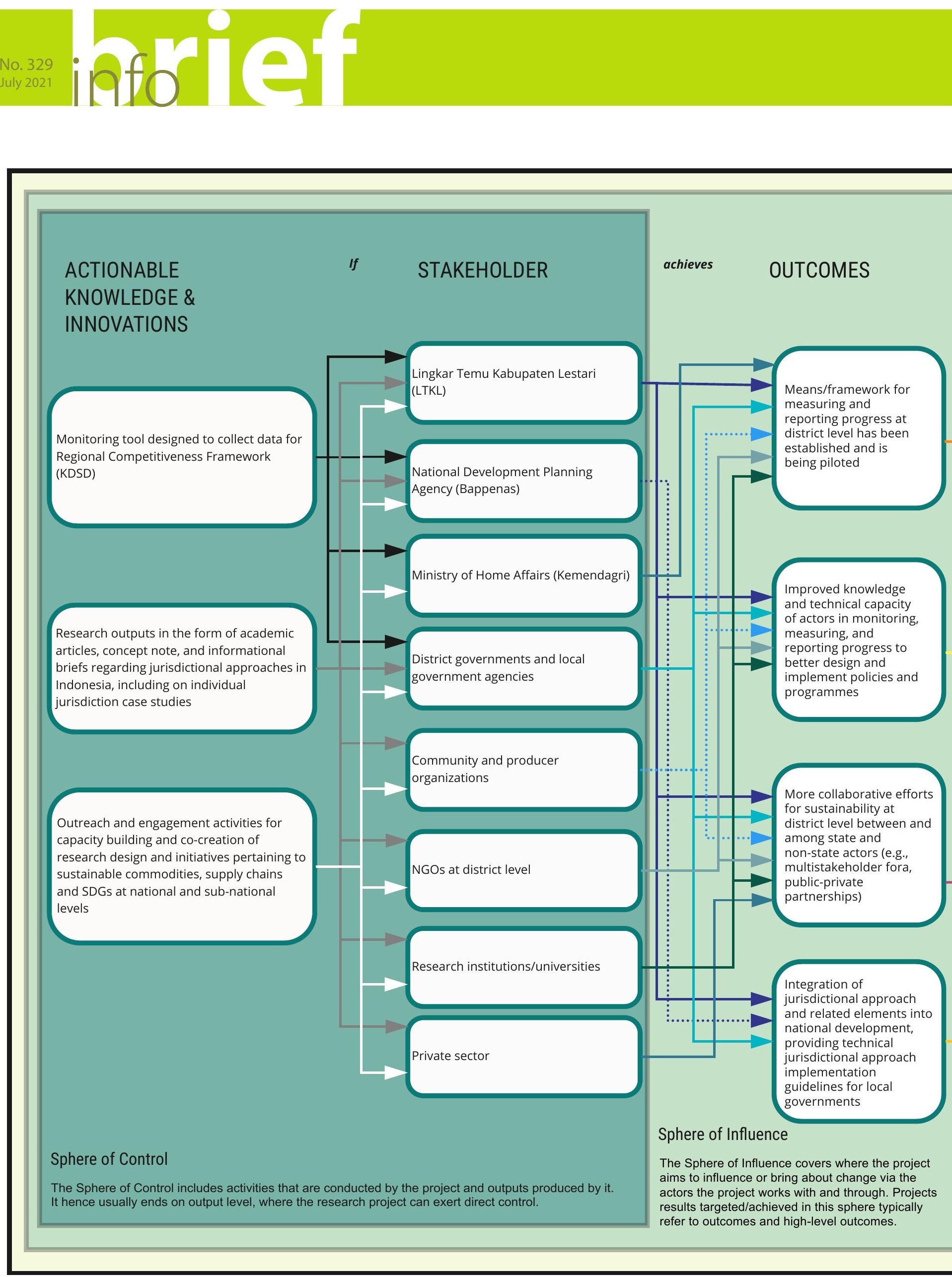

Figure 1. Theory of change describing the impact pathway for GCS REDD+ work on jurisdictional approaches in Indonesia Source: Authors' illustration 
thereby

contributing ULTIMATELY

lead to to EXPECTED IMPACTS
More credible monitoring \&

reporting systems and capacity lead to increased districts'

competitiveness and attractiveness for new investments/incentives for sustainability
District-level policies, strategies and planning support the realization of national development plans and SDGs by promoting sustainable commodity value chains

More district governments are encouraged to explore and implement initiatives related to sustainable commodities and SDGs
More subnational governments are encouraged to explore and implement a comprehensive 'green' economic reform, ensuring alignment and adherence of all sectors

Appearance of innovative incentive mechanisms for private sector involvement in green initiatives (e.g., premium price and low-interest loans for producers with good agricultural practices)

Increased land tenure security and sustained livelihood improvements for smallholders and local/ indigenous (adat) communities
Sustained increases in new and clean investments in Indonesian districts, contributing to new livelihood opportunities, reduced inequality, and economic growth/resilience
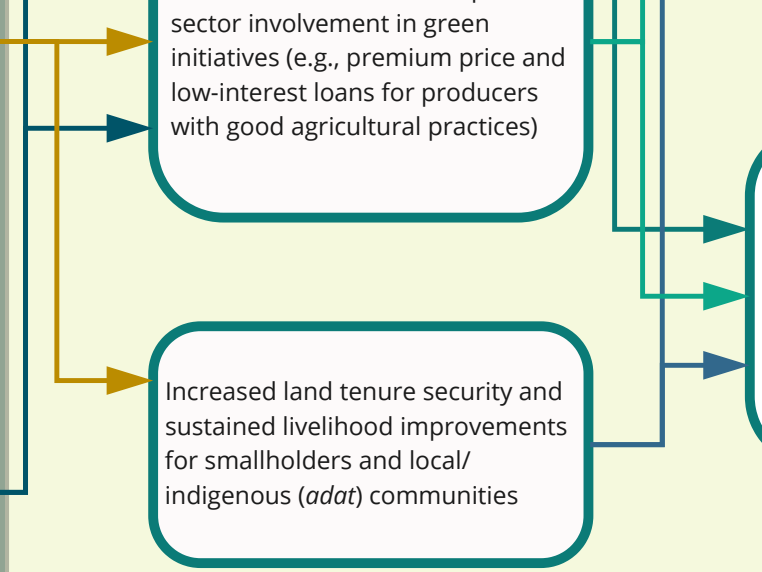

Sustained reductions in deforestation and forest/peatland degradation in Indonesian districts, increasing disaster and climate resilience

\section{Sphere of Interest}

The Sphere of Interest models indirect changes that fall outside of the direct influence of the project. These changes result in new uncertainties, which may manifest as outcomes or changes in the social economic, or environmental conditions. These changes result in new uncertainties, where new research entry points and questions are identified. Project results targeted/achieved in this sphere typically refer to intermediary impact and the expected ultimate impact level. 


\section{References}

Boyd W, Stickler C, Duchelle AE, Seymour F, Nepstad D, Bahar NHA and Rodriguez-Ward D. 2018. Jurisdictional approaches to REDD+ and low emissions development: Progress and prospects. Washington DC: World Resources Institute. https://www.cifor.org/ knowledge/publication/6933/

de Sassi C, Sunderlin WD, Sills EO, Duchelle AE, Ravikumar A, Resosudarmo IAP, Luttrell C, Joseph S, Herold M, Kweka DL and Atmadja SS. 2014. REDD+ on the ground: Global insights from local contexts. In Sills EO, Atmadja SS, de Sassi C, Duchelle AE, Kweka DL, Resosudarmo IAP and Sunderlin WD, eds. REDD+ on the ground: A case book of subnational initiatives across the globe. Bogor, Indonesia: CIFOR. https://www.cifor.org/knowledge/ publication/5284/

Duchelle AE, Greenleaf M, Mello D, Gebara MF and Melo T. 2014. Acre's State System of Incentives for Environmental Services (SISA), Brazil. In Sills EO, Atmadja SS, de Sassi C, Duchelle AE, Kweka DL, Resosudarmo IAP and Sunderlin WD, eds. REDD+ on the ground: A case book of subnational initiatives across the globe. Bogor, Indonesia: CIFOR. https://www2.cifor.org/redd-case-book/ case-reports/brazil/acres-state-system-incentives-environmentalservices-sisa-brazil/

Government of Indonesia. 2020. Rencana Pembangunan Jangka Menengah Nasional Tahun 2020-2024. Jakarta: Government of Indonesia.

Government of Sintang District. 2019. Rencana Aksi Daerah Sintang Lestari (RAD-SL) Period 2019-2021. Sintang: Government of Sintang District.

LTKL (Lingkar Temu Kabupaten Lestari). 2019. Jurisdictional approach in Indonesia: Progress to date. Jakarta: LTKL.

LTKL. n.d. Regional Competitiveness Framework. Jakarta: Lingkar Temu Kabupaten Lestari.

Peteru S, Duchelle AE, Stickler C, Durbin J, Luque C and Komalasari M. 2021. Participatory use of a tool to assess governance for sustainable landscapes. Frontiers in Forests and Global Change 4. https://doi.org/10.3389/ffgc.2021.507443

Ravikumar A, Larson AM, Duchelle AE, Myers R and Gonzales Tovar J. 2015. Multilevel governance challenges in transitioning towards a national approach for REDD+: Evidence from 23 subnational REDD+ initiatives. International Journal of the Commons 9:909-931. https://doi.org/10.18352/ijc.593

Sedagho Siak and Government of Siak District. 2019. Peta jalan Siak menuju kabupaten hijau: Pedoman untuk mendorong prinsip-prinsip kelestarian dan berkelanjutan dalam pemanfaatan sumberdaya alam dan peningkatan ekonomi masyarakat. Siak, Sumatra, Indonesia: Government of Siak District.
Seymour FJ, Aurora L and Arif J. 2020. The jurisdictional approach in Indonesia: Incentives, actions and facilitating connections. Frontiers in Forests and Global Change 3. https://doi.org/10.3389/ ffgc.2020.503326

Sills EO, Atmadja SS, de Sassi C, Duchelle AE, Kweka DL, Resosudarmo IAP and Sunderlin WD, eds. 2014. REDD+ on the ground: A case book of subnational initiatives across the globe. Bogor, Indonesia: CIFOR. https://doi.org/10.17528/cifor/005202 Stickler C, Duchelle AE, Ardila JP, Nepstad D, David O, Chan C, Rojas JG, Vargas R, Bezerra T, Pritchard I, et al. 2018a. The State of Jurisdictional Sustainability: Synthesis for Practitioners and Policymakers. San Francisco, CA and Bogor, Indonesia: Earth Innovation Institute and CIFOR. https://www.cifor.org/ knowledge/publication/6999/

Stickler C, Duchelle AE, Nepstad D and Ardila JP. 2018b. Subnational jurisdictional approaches: Policy innovation and partnership for change. In Angelsen A, Martius C, Sy VDS, Duchelle AE, Larson AM and Pham TT, eds. Transforming REDD+: Lessons and new directions. Bogor, Indonesia: CIFOR. https://www.cifor.org/ knowledge/publication/7072

Sukri W, Oktavianus B, Anastasia Parwadi F, Prawiyanto Y, Isnandar A, Subariyanti E, Hermanto, Firdaus, Epi P, Perdana ZHJ, et al. 2020. Sintang District, West Kalimantan, Indonesia: Low-emission rural development (LED-R) at a glance. In Stickler C, Duchelle AE, Ardila JP, Nepstad D, David O, Chan C, Rojas JG, Vargas R, Bezerra T, Pritchard I et al., eds. The State of Jurisdictional Sustainability: Synthesis for Practitioners and Policymakers. San Franscisco, CA and Bogor, Indonesia: Earth Innovation Institute and CIFOR. https:// www.cifor.org/knowledge/publication/7797/

Syahrani G, Istanti RP, Pasaribu PR, Peteru S and Duchelle AE. 2020. Lessons from Indonesia: Building a nature-based economy through jurisdictional approaches. White Paper produced by LTKL and CIFOR for the Global Landscapes Forum. https://www. globallandscapesforum.org/publication/lessons-from-indonesiabuilding-a-nature-based-economy-through-jurisdictionalapproaches/

Transformasi. 2017. 10 persen APBD Kabupaten Gorontalo untuk adaptasi perubahan iklim. Limboto, Gorontalo.

TFA (Tropical Forest Alliance). 2020. Learning from Jurisdictions: Data Collection for LTKL's Regional Competitiveness Framework (Webinar). https://www.tropicalforestalliance.org/en/news-andevents/events/learning-from-jurisdictions-data-collection-forItkls-regional-competitiveness-framework

Wunder S, Duchelle AE, de Sassi C, Sills EO, Simonet G and Sunderlin WD. 2020. REDD+ in theory and practice: How lessons from local projects can inform jurisdictional approaches. Frontiers in Forests and Global Change 3. https://doi.org/10.3389/ffgc.2020.00011

\begin{tabular}{|l|l|l|l} 
The CGIAR Research Program on Forests, Trees and Agroforestry (FTA) is the world's largest research for \\
development program to enhance the role of forests, trees and agroforestry in sustainable development \\
and food security and to address climate change. CIFOR leads FTA in partnership with Bioversity \\
International, CATIE, CIRAD, ICRAF, INBAR and TBI. \\
PROGRAM on \\
Forests, Trees and \\
Agroforestry
\end{tabular}

